\title{
PERSEBARAN NISAN ARCA DI SULAWESI SELATAN
}

(The Distribution of Statue Tombs in Sulawesi Selatan)

\section{Nurul Adliyah Purnamasari, Lenrawati, Desy Sriyati Limbong, M. Yusuf, dan Dwi Sumaiyyah M}

Balai Arkeologi Sulawesi Selatan

Jalan Pajjaiyyang Nomor 13, Sudiang Raya, Makassar, Indonesia.

Alumni Program Studi Arkeologi Pascasarjana Fakultas Ilmu Budaya Universitas Hasanuddin Jalan Perintis Kemerdekaan, Tamalanrea, Makassar, Indonesia.

Pos-el: nurul.adliyah@kemdikbud.go.id, lenrawati01@kemdikbud.go.id, desy.sriyati@kemdikbud.go.id, yusuf1985@kemdikbud.go.id, dwi.sumaiyyah14@.gmail.com

\begin{tabular}{|c|c|}
\hline & \\
\hline & \multirow{9}{*}{$\begin{array}{l}\text { The statue tomb is type of tomb that has a human-like shape. The } \\
\text { use of the statue as a tomb on an Islamic grave cannot be } \\
\text { separated from the influence of megalithic culture. This can be } \\
\text { proved by the discovery of menhir statues in several areas in } \\
\text { South Sulawesi and its nearby areas. Several previous studies } \\
\text { have revealed the existence of statues in several areas in Sulawesi } \\
\text { Selatan. This study was carried out as an effort to trace all library } \\
\text { data related to statues in South Sulawesi, both online and offline. } \\
\text { The results of the research then produced information on } 43 \\
\text { statue tombs spread across } 26 \text { ancient tomb sites in } 13 \text { regencies } \\
\text { / city, both in Bugis ethnical areas in Barru, Pinrang, Sidenreng } \\
\text { Rappang, Bone, Enrekang and East Luwu districts. Then in the } \\
\text { ethnic areas of Makassar area, statue tombs spread in Makassar, } \\
\text { Selayar Islands, Bulukumba, Bantaeng, Jeneponto, Takalar and } \\
\text { Maros Regency. }\end{array}$} \\
\hline & \\
\hline & \\
\hline etujui : $8 \mathrm{~A}$ & \\
\hline & \\
\hline & \\
\hline & \\
\hline & \\
\hline & \\
\hline
\end{tabular}

\begin{abstract}
ABSTRAK
Nisan arca merupakan tipe nisan yang memiliki bentuk menyerupai manusia. Penggunaan patung arca sebagai nisan pada kubur Islam tidak terlepas dari pengaruh budaya megalitik. Hal tersebut dibuktikan dengan penemuan arca menhir pada beberapa daerah di Sulawesi Selatan dan wilayah terdekatnya. Beberapa penelitian terdahulu telah mengungkapkan keberadaan nisan arca pada beberapa daerah di Sulawesi Selatan. Kajian ini kemudian dilakukan sebagai upaya untuk menelusuri seluruh data pustaka terkait nisan arca di Sulawesi Selatan, baik itu yang bersifat daring maupun luring. Hasil penelusuran tersebut kemudian menghasilkan informasi mengenai 43 nisan arca yang tersebar pada 26 situs kompleks makam kuno di 13 kabupaten/kota, baik itu pada wilayah etnik Bugis di Kabupaten Barru, Pinrang, Sidenreng Rappang, Bone, Enrekang dan Luwu Timur. Kemudian pada wilayah etnik Makassar nisan arca tersebar di Kota Makassar, Kabupaten Kepulauan Selayar, Bulukumba, Bantaeng, Jeneponto, Takalar dan Maros.
\end{abstract}




\section{PENDAHULUAN}

Periodesasi Islam di Sulawesi Selatan dimulai sejak abad ke-17. Hal tersebut ditandai dengan banyaknya situs dan peninggalan arkeologi Islam di wilayah Sulawesi Selatan, termasuk di antaranya adalah makam-makam kuno. Makam merupakan salah satu data penting dalam kajian arkeologi Islam, karena makam dianggap sebagai tempat peristirahatan terakhir sebelum ke alam baqa, sehingga dibuat dengan bentuk monumental (Mansyur, 2016, p. 46). Selain itu, makam dibuat dengan berbagai bentuk, gaya, ukuran maupun ragam hias yang mengandung makna tersendiri terkait tokoh yang dimakamkan. Tidak mengherankan jika banyak hal kesejarahan dan budaya yang mampu terjawab melalui kajian mendalam terhadap sebuah makam maupun kompleks makam.

Penelitian mengenai makam Islam di Sulawesi Selatan, pada dasarnya sudah sangat sering dilakukan, baik itu oleh kalangan peneliti, akademisi; dosen maupun mahasiswa. Berdasarkan data hasil penelitian Balai Arkeologi Sulawesi Selatan, Darmawan Mas'ud Rahman, Muhaeminah, Hasir Somba dan Sabiruddin Bila pada tahun 1994 pernah melakukan penelitian pada Kompleks Makam Islam di bagian selatan Kota Makassar dengan judul Seni Khat dan Ajaran Agama Islam di dalam Inskripsi Kaligrafi Arab dan
Lontara pada Makam Islam Bahagian Selatan Kotamadya Ujung Pandang. Penelitian yang dilakukan pada kompleks makam di Kabupaten Bantaeng, Je'neponto, Takalar, Gowa dan Kota Makassar ini menghasilkan informasi bahwa salah satu atribut yang ditemukan pada nisan makam di wilayah Etnik Makassar adalah seni ukir inskripsi arab dan lontarak. (Rahman et al., 1994).

Penelitian selanjutnya yang dilakukan oleh Muhaeminah tahun 1996 dengan judul Tipe Nisan Makam Kuno di Kecamatan Pammana Kabupaten Wajo menghasilkan informasi mengenai tipe-tipe nisan pada beberapa kompleks makam di Kabupaten Wajo, yaitu Tipe Bundar, Silindrik, Pipih dan Balok. Informasi mengenai tipe-tipe nisan di Sulawesi Selatan juga bisa ditemukan pada Laporan Penelitian Arkeologi: Kabupaten Wajo Sulawesi Selatan dari tahun 2010 yang dilakukan Balai Arkeologi Makassar melalui ketua tim Hasanuddin. Penelitian yang menghasilkan informasi mengenai karakteristik budaya pada situs arkeologi di Wajo ini juga mampu menunjukan beberapa tipe-tipe nisan, yaitu: nisan tipe mahkota, pipih, dan Aceh. Pada penelitian ini juga telah ditemukan jenis nisan yang mendapat pengaruh dari unsur pra-Islam yakni nisan tipe menhir pada Kompleks Makam Tempe, KLapute, Situs Alangkanange dan Makam Arung Tanete 
(Balai Arkeologi Makassar, 2010; Muhaeminah, 1996).

Selanjutnya, M. Irfan Mahmud tahun 2001 pada penelitian dengan judul "Determinasi Budaya Islami di Wilayah Pinggiran Kekuasaan Bugis" juga menemukan salah satu tipe nisan dengan unsur budaya lokal dari masa pra-Islam, yaitu nisan arca yang ditemukan pada Kompleks Makam Duri di Kabupaten Enrekang. Melalui penelitian tersebut diketahui bahwa nisan yang berbentuk patung manusia tersebut merupakan replika tokoh yang di makamkan (Mahmud, 2001). Penemuan tersebut menjadi begitu menarik, karena nisan arca merupakan salah satu ciri nisan khas di Sulawesi Selatan yang mampu menjadi salah satu perspektif dalam mengurai tekateki transisi budaya kubur dari periode praIslam ke periode Islam (Nur et al., 2019). Nisan arca sendiri merupakan tipe nisan yang memiliki bentuk menyerupai manusia dan keberadaannya ditemukan di beberapa wilayah di Sulawesi Selatan. Penggunaan patung arca sebagai nisan pada kubur Islam tidak terlepas dari pengaruh budaya megalitik. Hingga saat ini tradisi megalitik masih dapat dijumpai di berbagai wilayah di Indonesia. Bahkan mengalami akulturasi dengan budaya lainnya (Utomo, 2000, p. 14).

Beberapa penelitian terdahulu telah banyak menyebutkan keberadaan nisan arca di Sulawesi Selatan. Makam yang menggunakan patung arca sebagai nisan ditemukan pada kompleks makam tertentu yang berasosiasi makam-makam lainnya. Sayangnya nisan arca ditemukan dalam jumlah sedikit dibandingkan dengan tipetipe lainnya di Sulawesi Selatan.

Dimulai oleh Danang Wahyu Utomo, 2000 dengan judul "Pengaruh Tradisi dan Simbol Megalitik pada Makam Kuna Islam di Sulawesi Selatan”. Berdasarkan penelitian tersebut diketahui bahwa penggunaan nisan arca di Sulawesi Selatan sangat serupa dengan bentuk dan penggayaan relief-relief manusia yang dipahatkan pada waruga di Minahasa. Bentuk nisan dan motif menggambarkan pola pikir yang masih mengikuti tradisi sebelumnya, yaitu tradisi megalitik (Utomo, 2000).

Walaupun tidak secara khusus dikaji, nisan tipe arca juga dibahas dalam beberapa penelitian terkait makam dan nisan Islam di Sulawesi Selatan. Di antaranya adalah penelitian yang dilakukan oleh Muhaeminah pada tahun 2008 dengan judul "Kubur Islam Kuno di Pesisir Sulawesi Selatan dan Sulawesi Barat", dalam penelitian tersebut ditemukan nisan arca dengan bagian dada yang berbentuk segi empat dan duduk di atas kursi pada Kompleks Makam Raja-Raja Binamu di Je'neponto. Hasil Penelitian tersebut mengungkapkan bahwa nisan arca tidak 
hanya menampilkan tokoh si mati, tetapi juga sebagai personifikasi arwah leluhur yang memiliki kekuatan (Muhaeminah, 2008).

Penelitian dengan judul "Potensi dan Sebaran Arkeologi Masa Islam di Sulawesi Selatan" yang dilakukan oleh Muhammad Husni dan Hasanuddin tahun 2011 juga mengungkapkan adanya temuan nisan arca manusia di Kabupaten Je'neponto dan Bantaeng. Penelitian selanjutnya yang mengungkap penemuan nisan arca di Sulawesi Selatan dilakukan oleh Samsir Bahrir melalui skripsi dengan judul "Perbandingan Bentuk dan Ragam Hias Nisan Makam Islam pada Wilayah Pesisir Dan Wilayah Pedalaman di Sulawesi Selatan" pada tahun 2009, Bahrir menyebutkan adanya penemuan nisan arca pada Kompleks Makam Laiya Alla di Enrekang dan Kompleks Makam Binamu di Je'neponto (Bahrir, 2009; Husni \& Hasanuddin, 2011).

Penelitian yang dilakukan oleh Erwin Mansyur tahun 2016 dengan judul "Fenomena Akulturasi dan Sinkretisme dalam Perspektif Arkeologi: Ragam Hias di Kompleks Makam Bataliung Je'neponto Sulawesi Selatan", mengungkapkan adanya pemakaian nisan arca pada beberapa kompleks makam di antaranya; Kompleks Makam Bataliung, dan Karaeng Sennge di Tarowang Je'neponto, kompleks makam Islam kuno di daerah Bantaeng dan
Takalar, serta kompleks pemakaman masyarakat kajang di Bulukumba. Menurut Mansyur, diduga penggunaan nisan arca ini dimaksudkan sebagai sarana perbadanan roh orang yang meninggal, serta berkaitan dengan kepercayaan dan pemujaan kepada roh leluhur yang dianggap sebagai orang terdekat dengan Tuhan (Mansyur, 2016).

Penelitian selanjutnya dilakukan oleh Muhammad Nur pada tahun 2017 dengan judul "Unsur Budaya Prasejarah dan Tipo-Kronologi di Kompleks Makam Mattakko, Maros, Sulawesi Selatan", dalam penelitian tersebut diungkapkan adanya nisan arca di Kompleks Makam Mattakko yang membuktikan bahwa tradisi pra-Islam masih kuat pengaruhnya pada masyarakat hingga awal perkembangan Islam di Sulawesi Selatan. Selanjutnya nisan arca yang memperlihatkan bagian kepala dengan bagian muka yang lengkap mulai dari mata, alis, hidung, mulut dan telinga ditemukan pada Kompleks Makam Latenri Ruwa di Bantaeng melalui penelitian yang dilakukan oleh Makmur dan Tim dengan judul Laporan Penelitian Arkeologi Jejak Peradaban Islam dan Kolonial di Kabupaten Bantaeng, Sulawesi Selatan pada tahun 2017 (Makmur, 2017a; Nur \& Hasanuddin, 2017).

Penelitian khusus mengenai nisan arca juga pernah dilakukan oleh Bau Mene tahun 2011 dengan Judul "Nisan Arca Situs Makam Kuno Manuba Kecamatan 
Mallusetasi Kabupaten Barru". Nisan arca tersebut ditemukan pada dua situs makam kuno, yaitu Situs Makam Kuno Pallae dan Situs Makam Kuno Allakkang. Berdasarkan hasil penelitian tersebut, Mene mengungkapkan bahwa nisan arca digunakan karena adanya kepercayaan pada masa lampau yang berkaitan erat dengan pemujaan terhadap arwah leluhur. Arca tersebut dianggap sebagai personifikasi nenek moyang yang telah meninggal, sehingga dibuat menyerupai orang tersebut. Selain itu, nisan arca juga mampu mengungkap stratifikasi sosial orang yang dimakamkan (Mene, 2011).

Penelitian lainnya dilakukan oleh Muhammad Nur, Hasanuddin, Akin Duli dan Rosmawati pada tahun 2019 dengan judul "Transformasi Arca Menhir menjadi Nisan Arca di Wilayah Makassar, Sulawesi Selatan, Indonesia". Penelitian tersebut melakukan kajian terhadap sepuluh arca menhir di Situs Borong Kapala Kecamatan Tompo Bulu Kabupaten Bantaeng. Penelitian ini mengungkapkan mengenai adanya tradisi pengarcaan manusia yang kuat berkembang di wilayah komunitas etnik Makassar lalu ditransformasikan menjadi nisan arca berbentuk manusia pada periode Islam. Hal tersebut dibuktikan dengan adanya Tujuh kompleks makam Islam yang memakai nisan arca manusia di wilayah etnik Makassar (Nur et al., 2019).
Penelitian ini sendiri berbeda dari penelitian-penelitian terdahulu yang hanya membahas terkait keberadaan nisan arca pada satu situs atau kawasan budaya tertentu. Oleh karena itu, penelitian ini dilakukan sebagai sebuah upaya untuk menelusuri keberadaan nisan arca di Sulawesi Selatan melalui data penelitian terdahulu, yang telah dipaparkan pada bagian sebelumnnya. Pertanyaan utama yang diajukan adalah: Bagaimana persebaran wilayah penemuan nisan arca di Sulawesi Selatan? Penelitian ini diharapkan mampu memberikan gambaran mengenai keberadaan seluruh nisan arca di Sulawesi Selatan sebagai sebuah data awal, sebelum dilakukannya kajian-kajian mendalam di masa yang akan datang.

\section{METODE PENELITIAN}

Penelitian ini dilakukan dengan metode desk study yaitu melakukan penelusuran data sekunder. Seluruh proses penelitian dilaksanakan pada bulan Oktober hingga November 2020. Ada beberapa tahapan yang dilakukan dalam penelitian ini, yaitu:

1. Pengumpulan data pustaka, tahapan ini dilakukan dengan penelusuran sumber referensi tertulis dan gambar berkaitan dengan nisan arca di Sulawesi Selatan, baik itu dari buku, artikel ilmiah, laporan penelitian Balai Arkeologi, laporan zonasi, studi teknis dan penyelamatan Balai Pelestarian Cagar 
Budaya, skripsi, tesis maupun disertasi, serta sumber referensi daring.

2. Analisis data, pada tahapan ini seluruh data kemudian diolah dan analisis untuk menghasilkan informasi sesuai dengan pertanyaan penelitian dan tujuan yang ingin dicapai dalam penelitian desk study ini. Pada tahapan ini juga dilakukan proses penggambaran peta digital untuk melihat persebaran situs dengan temuan nisan arca di Sulawesi Selatan.

3. Interpretasi data, Interpretasi data merupakan tahapan akhir dalam proses penelitian ini, yaitu dengan melakukan penafsiran atau penarikan kesimpulan terhadap seluruh data yang telah dikumpulkan dan dianalisis. Pada tahapan ini seluruh pertanyaan penelitian bisa terjawab.

\section{HASIL DAN PEMBAHASAN}

Sulawesi Selatan adalah provinsi dengan Ibu Kota Makassar, terdiri dari 21 kabupaten, yaitu: Kepulauan Selayar, Bulukumba, Bantaeng, Jeneponto, Takalar, Gowa, Sinjai, Maros, Pangkajene dan Kepulauan, Barru, Bone, Soppeng, Wajo, Sidenreng Rappang, Pinrang, Enrekang, Luwu, Tana Toraja, Luwu Utara, Luwu Timur, Toraja Utara, serta tiga kota madya, yaitu: Makassar, Pare-pare dan Palopo. Sulawesi Selatan dihuni oleh tiga etnik besar, yaitu Etnik Makassar, Bugis dan
Toraja, serta beberapa sub etnik lainnya (BPS Provinsi Sulawesi Selatan, 2019, pp. 3-4). Etnik Bugis pada dasarnya menghuni wilayah bagian utara Provinsi Sulawesi Selatan, yaitu pada Kabupaten Maros (sebagian), Pangkajene dan Kepulauan (sebagian), Barru, Pinrang, Pare-pare, Sinjai, Soppeng, Bone, Wajo, Sidenreng Rappang, Kota Pare-pare, daerah Luwu, Luwu Utara, Luwu Timur, Palopo, Bulukumba (sebagian) serta Enrekang (sebagian) (Saprillah; et al., 2012, p. 35; Sitonda, 2013, pp. 3-6; Syukur, 2015, p. 25; Wardaninggar, 2016, p. 113). Wilayah Etnik Makassar meliputi daerah Gowa, Makassar, Takalar, Je'neponto, Bantaeng, Kepulauan Selayar, Bulukumba (sebagian), Maros (sebagian) dan Pangkaje'ne dan Kepulauan (sebagian). Kemudian Etnik Toraja meliputi daerah Toraja, Toraja Utara, Luwu (sebagian) dan Enrekang (sebagian) (Sande et al., 1997, p. 2).

\section{Persebaran Nisan Arca di Wilayah Etnik Bugis}

\section{Kabupaten Barru}

Nisan arca di Kabupaten Barru ditemukan pada dua kompleks makam Islam, yaitu Kompleks Makam Raja-raja Nepo dan Situs Makam Kuno Allakkang, di Desa Manuba, Kecamatan Mallusetasi. Kompleks Makam Raja-raja Nepo terletak pada Koordinat $4^{\circ} 12^{\prime} 26.9^{\prime}$ S, $119^{\circ} 39^{\prime}$ 
34.9" E dan Situs Makam Kuno Allakkang pada koordinat $4^{\circ} 12^{\prime} 38.66^{\prime \prime} \mathrm{S}, 119^{\circ} 39^{\prime}$ $3.50 " \mathrm{E}$.

Secara morfologi kedua nisan arca tersebut memiliki kesamaan, yakni morfologi berbentuk persegi panjang yang terdiri dari kepala hingga pinggul. Memiliki muka bulat, mata berupa garis tipis panjang, telinga panjang, memakai topi haji dan kalung tasbih, serta kedua tangan terletak di atas perut dalam posisi silang menyerupai orang sholat. Patung terkesan memakai pakaian (Mene, 2011, pp. 43-44).

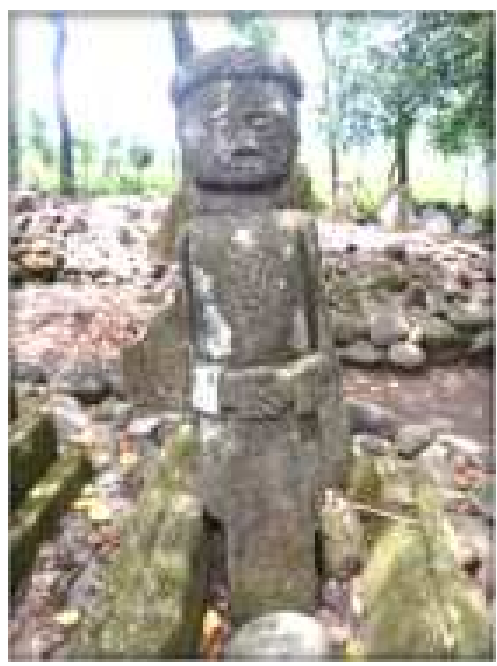

Gambar 1. Nisan Arca di Kompleks Makam Allakkang

(Sumber: Purnamasari, 2020)

\section{Kabupaten Bone}

Nisan arca di Kabupaten Bone ditemukan pada tiga situs arkeologi, dua diantara berada pada bekas pemukiman Kuno Cenrana. Kompleks Makam Nisan Arca dan Kompleks Makam Jaramele'e terletak di Desa Nagauleng, Kecamatan Cenrana. Masing-masing situs berada pada koordinat $4^{\circ} 19^{\prime} 48^{\prime \prime} \mathrm{S}, 120^{\circ} 19^{\prime} 16^{\prime \prime} \mathrm{E}$ dan
4 $19^{\prime} 49.469 " \mathrm{~S}, 120^{\circ} 19^{\prime} 11.766^{\prime \prime}$ E. Nisan pada Kompleks Makam Nisan Arca berbentuk setengah badan dengan tonjolan seperti gelung rambut di atas kepala dan tidak menggunakan pakaian, sedangkan nisan pada Kompleks Makam Jaramele'e secara anatomis terdiri dari Kepala, wajah, badan dan tangan dengan posisi duduk (BPCB Sulsel, 2019; Mahmud, 2000b, pp. 44-48, 2000a; Sarjiayanto, 2000, p. 73; Wulandari, 2011, p. 70, 2017, p. 106).

Nisan arca selanjutnya ditemukan pada Kompleks Makam Boccoe yang terletak di Dusun Kalukue, Desa Langi, Kecamatan Bontocani. Secara astronomis terletak pada 5 $05^{\prime} 03^{\prime \prime} \mathrm{S}, 119^{\circ} 58^{\prime} 8.48^{\prime \prime} \mathrm{E}$. Nisan arca yang ditemukan pada kompleks makam ini adalah tipe balok, dengan sisi utara yang berbentuk kepala manusia, sedangkan bagian selatan memiliki motif garis dan pahat. Berbahan sedimen pasir dengan tinggi dari permukaan tanah $20 \mathrm{~cm}$, lebar $14 \mathrm{~cm}$ dan tebal $10 \mathrm{~cm}$ (BPCB Makassar, 2013, pp. 43-50).

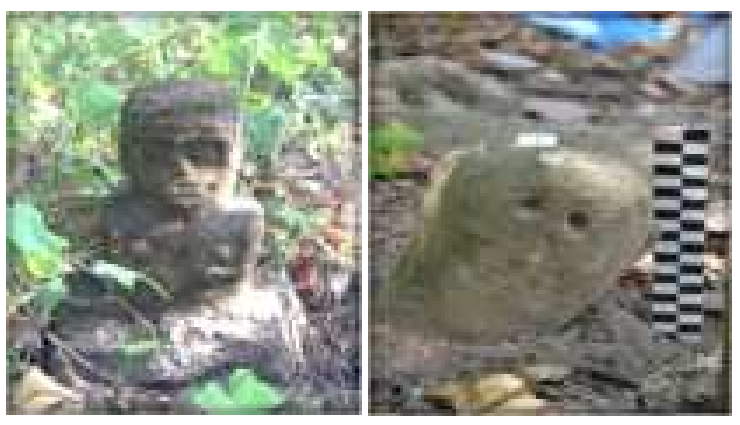

Gambar 2. a. Nisan Arca di Kompleks Makam Jaramele'e dan b. Kompleks Makam Boccoe

(Sumber: BPCB Sulsel, 2019) 


\section{Kabupaten Pinrang}

Dua nisan arca ditemukan di Kabupaten Pinrang. Nisan pertama ditemukan di Jalan Melati No. 63, Kelurahan Penrang, Kecamatan Watang Sawitto pada koordinat $3^{\circ} 48^{\prime} 24.89 " \mathrm{~S}$, $119^{\circ} 39^{\prime} 2.30^{\prime \prime}$ E. Secara morfologi nisan arca ini memiliki hiasan khusus berupa segi tiga di atas kepala, telapak tangan menghadap ke atas, serta terdapat hiasan pada bagian belakang yang menyerupai ikat pinggang (Balai Pelestarian Cagar Budaya Sulawesi Selatan, 2020).

Nisan arca kedua ditemukan pada Situs Makam IX Puang Tallu Tombinna yang terletak di Daerah Letta Kecamatan Lembang dengan koordinat $3^{\circ} 29^{\prime} 41.10^{\prime \prime}$ S, $119^{\circ} 38^{\prime}$ 53.97' E. Nisan arca dilengkapi dengan atribut berupa wajah dengan mata tertutup, hidung, mata dan telinga. Pada bagian badan dilengkapi dengan tangan (Iskandar, 2015, pp. 129-130).

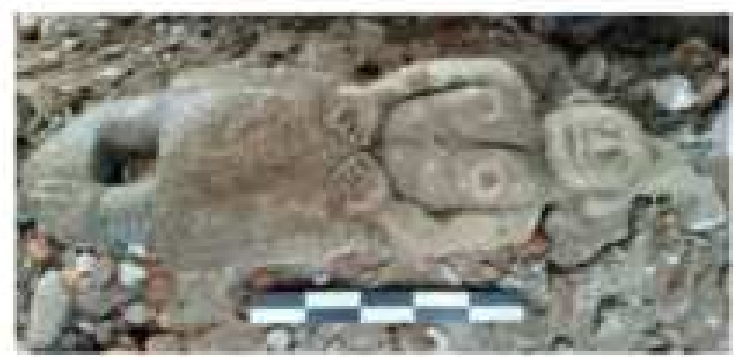

Gambar 3. Nisan Arca di Wattang Sawitto (Sumber: Balai Pelestarian Cagar Budaya Sulawesi Selatan, 2020)

\section{Kabupaten Sidenreng Rappang}

Kompleks Makam Sulewatang Sando Batu X adalah areal penemuan nisan arca di Kabupaten Sidenreng Rappang yang terletak di Desa Compong, Kecamatan Pitu Riase, Kabupaten Sidrap. Berada pada titik koordinat $3^{\circ} 44^{\prime} 1.85^{\prime \prime} \mathrm{S}, 120^{\circ} 8$ ' $2.55^{\prime \prime} \mathrm{E}$. Nisan tersebut memiliki tinggi $40 \mathrm{~cm}$ yang terbuat dari batu andesit (Iskandar, 2015, pp. 81-82). Berdasarkan pada foto, secara anatomi nisan ini terdiri dari muka dengan atribut pendukung seperti mata, serta badan dengan tangan yang tampak terlipat diperut.

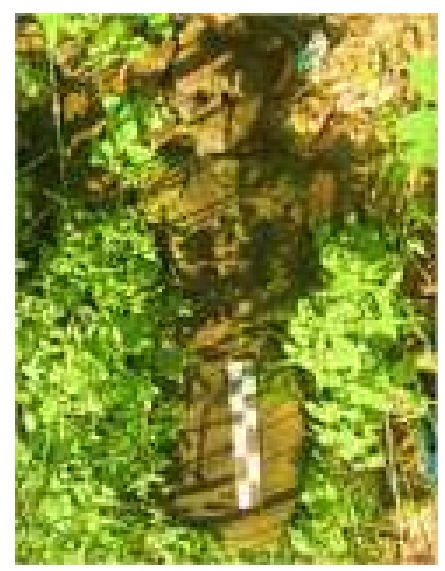

Gambar 4. Nisan Arca di Situs Makam Sulewatang Sando Batu X (Sumber: Iskandar, 2015)

\section{Kabupaten Enrekang}

Ada empat kompleks makam di Kabupaten Enrekang sebagai areal penemuan nisan arca. Kompleks Makam pertama yakni Kompleks Makam Laiya Alla yang terletak di Kampung Laiya, Kelurahan Kambiolangi, Kecamatan Alla, dengan titik koordinat $3^{\circ} 19^{\prime} 34.9^{\prime \prime} \mathrm{S}, 119^{\circ}$ 48' 01.1" E. Pada kompleks makam ini ditemukan tiga buah nisan arca, nisan arca pertama secara morfologis memiliki badan berbentuk bulat, dengan kepala yang dilengkapi dengan atribut mata, hidung, telinga berbentuk bulan sabit, dan tangan. 
Seluruh atribut dibuat dengan sangat sederhana. Nisan arca kedua memiliki kesamaan dengan nisan arca 1, yaitu badan bulat kepala yang dilengkapi dengan atribut mata, hidung, telinga berbentuk bulan sabit, dan tangan. Seluruh atribut dibuat dengan sangat sederhana. Terakhir nisan arca ketiga ditemukan dengan morfologis badan berbentuk bulat, tinggi mencapai $27 \mathrm{~cm}$ dan diameter $51 \mathrm{~cm}$. Bagian atas nisan membentuk kepala manusia dengan atribut sepasang mata dengan bentuk tidak beraturan, dilengkapi dengan mulut berupa garis datar yang aus (Bahrir, 2009, p. 102; Rosmawati, 2013, pp. 305-307).

Situs selanjutnya yaitu Kompleks Makam Baroko yang terletak di Desa Baroko, Kecamatan Alla, dengan titik koordinat $3^{\circ} 18^{\prime} 33.0^{\prime \prime} \mathrm{S}, 119^{\circ} 48^{\prime} 03.0^{\prime \prime} \mathrm{E}$. Berdasarkan identifikasi pada foto, diketahui bahwa nisan ini secara morfologis bertipe sederhana, dengan kepala dan badan bersambung, berbentuk bulan panjang. Memiliki atribut dua lingkaran menyerupai mata dan hidung di antara kedua lingkaran (Rosmawati, 2013, pp. 309-311).

Situs ketiga yaitu Kompleks Makam Bantu Tangla terletak di Jalan Garoga, Kampung Buntu Tangla, Desa Masalle, Kecamatan Masalle pada koordinat $3^{\circ} 20^{\prime} 44.5^{\prime \prime} \mathrm{S}, 119^{\circ} 44^{\prime} 53.7^{\prime \prime}$ E. Pada kompleks makam ini ditemukan dua nisan arca yang dibentuk dengan tidak sempurna. Bagian leher memperlihatkan lekukan, bagian kepala berbentuk bulat, dengan muka yang dibuat rapat tanpa panca indera (BPCB Sulsel, 2014, pp. 30-34).

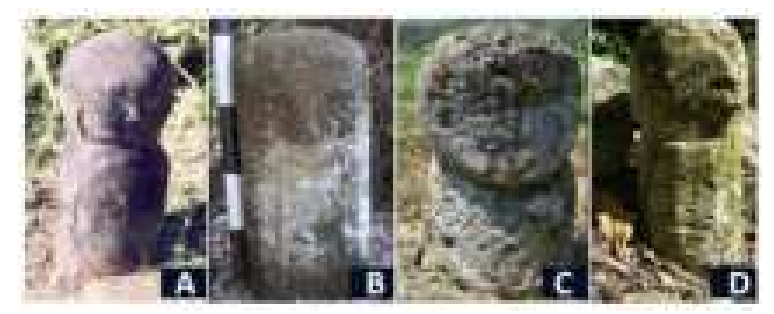

Gambar 5. a. Nisan arca di Kompleks Makam Laiya Alla, b. Kompleks Makam Baroko, c. Kompleks Makam Baroko (Enrekang) dan d. Kompleks Makam Raja-raja Alla.

(Sumber: Rosmawati, 2013 dan BPCB Makassar, 2014)

\section{Kabupaten Luwu Timur}

Nisan arca di Kabupaten Luwu Timur ditemukan di Kompleks Makam Islam Matano yang terletak di Desa Matano, Kecamatan Nuha, dengan titik koordinat $2^{\circ} 27^{\prime} 21.28^{\prime \prime} \mathrm{S}, 121^{\circ} 12^{\prime} 54.04$ ” E. Ada dua nisan arca yang ditemukan, nisan pertama adalah La Makandiu berbentuk patung manusia yang duduk di atas binatang, memegang senjata dengan ukuran yang tidak terlalu besar. Nisan kedua milik La Makandiu, tanpa lengan dengan bentuk menyerupai kepala ikan Hiu yang menghadap ke belakang (Azis, 1995, pp. 29-32).

Persebaran Nisan Arca di Wilayah Etnik Makassar

Kabupaten Bantaeng 
Terdapat tiga kompleks makam Islam di Kabupaten Banteng dengan tinggalan berupa nisan arca. Situs pertama yaitu Kompleks La Tenri Ruwa yang terletak di Kelurahan Palantikang, Kecamatan Bantaeng dengan titik koordinat $5^{\circ} 32^{\prime} 43.719^{\prime \prime} \mathrm{S}, 119^{\circ} 57^{\prime} 15.8^{\prime \prime}$ E. Pada kompleks makam ini ditemukan tiga buah nisan yang secara morfologis memperlihatkan bagian kepala, dengan bagian-bagian muka yang lengkap dengan mata, alis, hidung, mulut dan telinga (Makmur, 2017a, pp. 16-17).

Selain itu, nisan arca juga ditemukan pada Situs Lampporo, terletak di daerah dataran tinggi dengan elevasi 6000 mdpl. Secara administrasi situs ini berada di Kampung Lampporo, Desa Bonto Karaeng, Kecamatan Sinoa dengan titik koordinat $5^{\circ} 28^{\prime} 25.6^{\prime \prime} \mathrm{S}, 119^{\circ} 55^{\prime} 02.4^{\prime \prime} \mathrm{E}$. Nisan arca tersebut terdiri dari wajah dengan mata, hidung dan bibir, badan dengan tangan kanan berada di dada dan tangan kiri berada di perut (Makmur, 2017a, pp. 35-37).

Situs ketiga yaitu Kompleks Makam Lanynying yang berada di wilayah administratif Jalan Buakang Paliang, Kampung Buakang Paliang, Desa Bonto Lojong, Kecamatan Ulu Ere pada titik koordinat $5^{\circ} 26^{\prime} 17.8^{\prime \prime} \mathrm{S}, 119^{\circ} 56^{\prime} 5.31^{\prime \prime} \mathrm{E}$. Informasi mengenai keberadaan nisan arca di situs ini diperoleh melalui artikel yang ditulis oleh Nur, et al tahun 2019 (Nur et al.,
2019). Nisan tersebut berbentuk bulat, terdiri dari kepala dan badan. Bagian kepala memiliki garis yang membentuk mata bulat seperti berkaca mata, hidung dan mulut, serta telinga berukuran besar. Kemudian bagian belakang kepala terdapat sebuah tonjolan bulat yang tampak seperti sanggul.

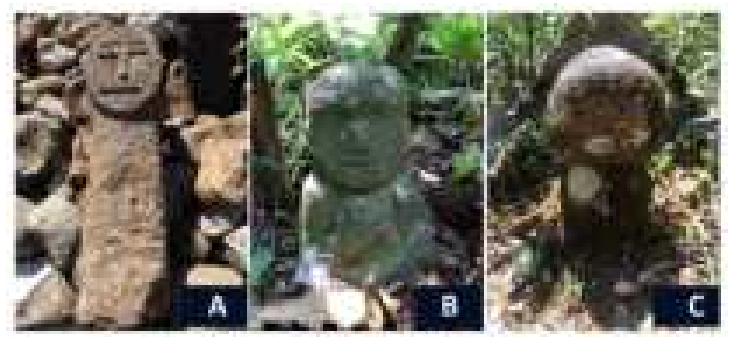

Gambar 6. a. Nisan Arca di Kompleks Makam La Tenri Ruwa, b. Situs Lampporo, c. Kompleks Makam Lanynying (Sumber: Purnamasari, 2020)

\section{Kabupaten Jeneponto}

Kompleks Makam Raja-raja Binamu adalah satu dari empat kompleks makam Islam di Jeneponto dengan nisan berbentuk arca. Terletak di Desa Bontoramba, Kecamatan Bontoramba, Kabupaten Jeneponto. Secara geografis situs ini berada pada koordinat $5^{\circ} 41^{\prime} 37.9$ S, $119^{\circ} 43^{\prime} 27.3^{\prime \prime}$ E. Ada lima buah nisan arca pada kompleks makam ini, namun empat di antaranya telah hilang. Nisan arca yang saat ini ditemukan adalah milik $I$ Palengkei Daeng Lagu. Nisan tersebut memiliki bagian yang kompleks dengan kepala berbentuk oval menggunakan songkok atau peci, atribut pada muka yang terdiri dari mata, alis, hidung, bibir dan telinga. Badan tegak serta ukuran kaki 
yang kecil. Tangan diletakkan pada lengan kursi yang masing-masing memiliki lima jari (Bahrir, 2009, pp. 111-112; Jamaluddin, 1990, pp. 37-39; Tim Peneliti Balai Arkeologi Sulawesi Selatan, 2011, pp. 28-30).

Berjarak sekitar 1 kilometer dari Kompleks Makam Raja-raja Binamu, Kompleks Makam Joko terletak Desa Bangkala, Kecamatan Bontoramba pada koordinat 5 $5^{\circ} 36^{\prime} 29.1^{\prime \prime} \mathrm{S}, 119^{\circ} 42^{\prime} 40.4$ " E. Secara morfologis kedua nisan arca pada kompleks makam ini memiliki struktur badan yang kompleks, terdiri dari kepala hingga kaki. Nisan arca ini juga berada pada posisi duduk di atas singgasana berukiran motif flora (Kementerian Pendidikan dan Kebudayaan Balai Pelestarian Peninggalan Purbakala, 2012, pp. 69-70; Suaka Peninggalan Sejarah dan Purbakala Sulawesi Selatan, 1983, pp. 1617).

Kemudian Kompleks Makam Syekh ri Poko Bulo yang terletak Kampung Poko Bulo, Desa Bangkala Loe, Kecamatan Bonto Ramba. Berada kurang lebih 1 km di sebelah timur laut Kompleks Makam Joko dengan titik koordinat $5^{\circ} 36^{\prime} 10.2^{\prime} \mathrm{S}, 119^{\circ}$ $43^{\prime} 11.6^{\circ}$ E. Nisan arca pada kompleks makam ini telah kehilangan bagian kepala hingga dada, sehingga hanya terlihat bagian perut dan kaki pada posisi duduk (Kementerian Pendidikan dan Kebudayaan Balai Pelestarian Peninggalan Purbakala,
2012, p. 72; Suaka Peninggalan Sejarah dan Purbakala Sulawesi Selatan, 1984, p. 18).

Berada di wilayah perbatasan Kabupaten Jeneponto dan Bantaeng, Kompleks Makam Karaeng Sengge secara administratif terletak di Kampung Loe, Desa Balangloe Tarowang, Kecamatan Tarowang, Kabupaten Jeneponto. Kompleks makam ini terletak di pinggir jalan, tepat di samping Kantor Desa Balangloe Tarowang. Secara geografis berada pada titik koordinat $5^{\circ} 35^{\prime} 40.8$ ' $\mathrm{S}$, $119^{\circ} 53$ ' 4.2" E. Nisan arca yang ditemukan pada kompleks makam ini berbentuk pipih, terdiri dari kepala berbentuk oval yang menggunakan songkok Haji, memiliki telinga dengan wajah yang terdiri dari alis, mata tanpa bola, hidung dan mulut tertutup. Tangan melipat ke dada, tampak seperti orang yang sedang sholat (Kementerian Pendidikan dan Kebudayaan Balai Pelestarian Peninggalan Purbakala, 2012, pp. 54-55).

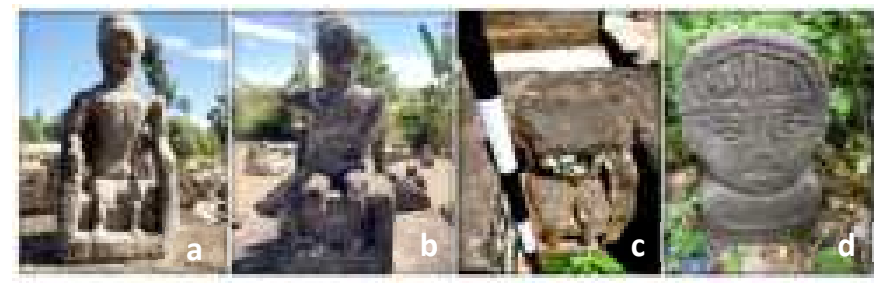

Gambar 7. a. Nisan Arca di Kompleks Makam Raja-raja Binamu, b. Kompleks Makam Joko, c. Kompleks Makam Syekh ri Poko Bulo, d. Kompleks Makam Karaeng Sengge

(Sumber: Purnamasari, 2020)

\section{Kabupaten Bulukumba}


Dua situs penemuan nisan arca di Bulukumba terletak di Kecamatan Kajang, yaitu Situs Makam Ammatoa dan Kompleks Makam Kuna Karaeng Dea Daeng Lita. Pada Kompleks Makam Kuno Karaeng Dea Daeng Lita yang terletak Kelurahan Tanah Jaya dengan titik koordinat $05^{\circ} 20^{\prime} \quad 15.27^{\prime \prime} \mathrm{S}, 120^{\circ} 22^{\prime}$ 09.07" E memiliki tiga buah tinggalan nisan arca. Ketiganya terdiri dari kepala dan badan yang berbentuk bulat lonjong, puncak kepala bulat, tidak memiliki kaki dan bahu. Kemudian Kompleks Makam Ammatoa Kajang terletak pada koordinat $5^{\circ} 19^{\prime} 58.8$ " S, $120^{\circ} 21^{\prime} 50.83$ " E. Nisan arca pada situs ini dideskripsikan memiliki motif dan garis yang menyerupai manusia (Makmur, 2017b, p. 17; Natsir et al., 2011, p. 36; Zerasmita, 2007, p. 79).

\section{Kabupaten Kepulauan Selayar}

\section{Kompleks Makam Batangmata} merupakan areal penemuan nisan arca di Kepulauan Selayar, terletak di Kecamatan Bontomate'ne dengan posisi geografis berada pada $50^{\circ} 55^{\prime} 37.65^{\prime \prime} \mathrm{S}, 120^{\circ} 26^{\prime}$ 53.64" E. Salah satu bentuk nisan yang ditemukan pada kompleks makam ini yaitu nisan arca dengan ragam hias berbentuk sulur-suluran, bunga, hiasan tumpal dan kaligrafi Arab (Balai Pelestarian Peninggalan Purbakala Sulawesi Selatan, 2006).

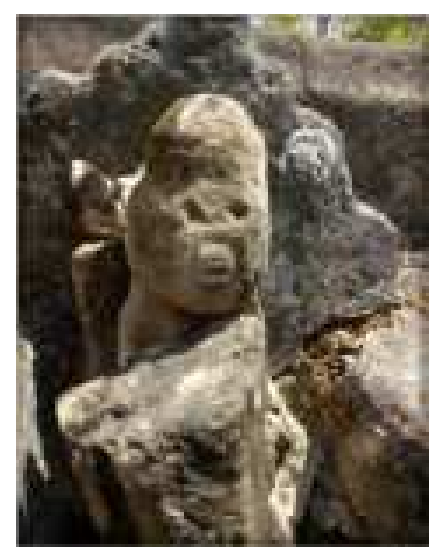

Gambar 8. Nisan Arca di Kompleks Makam Batangmata

(Sumber: Lenrawati, 2020)

\section{Kabupaten Takalar}

Nisan arca di Kabupaten Takalar ditemukan di Kompleks Makam Kompleks Makam Paduai Daeng Palallo yang terletak di Kampung Malilaya, Desa Punaga, Kecamatan Mangngarabombang pada koordinat $05^{\circ} 34^{\prime} 29.5^{\prime \prime} \mathrm{S}, 119^{\circ} 25^{\prime} 43.2^{\prime \prime}$ E. Nisan arca yang ditemukan terbuat dari batu padas dengan tinggi $34 \mathrm{~cm}$, lebar 12 $\mathrm{cm}$, dan tebal $7 \mathrm{~cm}$ (Muhaeminah, 2008, pp. 65-66).

\section{Kota Makassar}

Kompleks Makam Raja-Raja Sudiang terletak di Kelurahan Sudiang, Kecamatan Biringkanaya. Berada pada koordinat $5^{\circ} 6^{\prime} 2^{\prime \prime} \mathrm{S}, 119^{\circ} 32^{\prime} 23^{\prime \prime}$ E. Nisan arca yang ditemukan pada kompleks makam ini berbentuk patung kepala manusia dengan tinggi $20 \mathrm{~cm}$ dan terletak di sebelah utara makam. Terbuat dari batu dengan bentuk kepala seperti bulat telur (Hasnawati, 1995, p. 32). 


\section{Kabupaten Maros}

Nisan arca di Kabupaten Maros ditemukan pada Kompleks Makam Mattako yang terletak di Kampung Bonto Biraeng, Desa Bonto Manai, Kecamatan Marusu', dengan koordinat 5० 1' 19.7' S, $119^{\circ} 30^{\prime}$ 53.9” E (Nur \& Hasanuddin, 2017, p. 61). Ada empat nisan arca yang ditemukan pada kompleks makam ini, secara morfologi nisan tersebut berbentuk pipih, dengan dua lingkaran yang menyerupai mata, di antara kedua lingkaran ada sebuah tonjolan bergaris vertikal. Kedua atribut tersebut ditemukan pada kedua sisi lebar nisan. Pada bagian puncaknya terdapat tiga jejar hiasan yang meruncing.
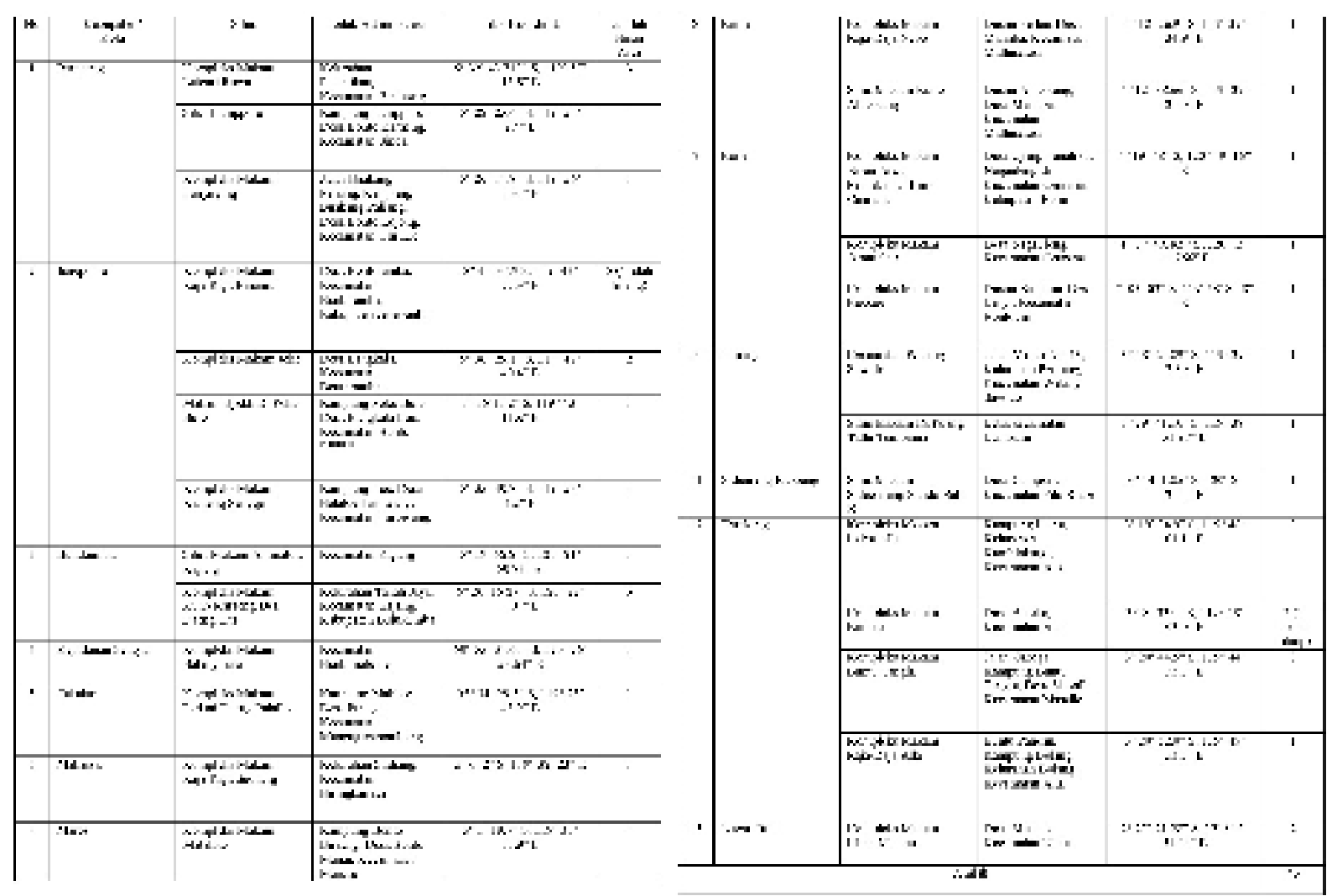

Tabel 1. Persebaran Nisan Arca di Sulawesi Selatan

Jurnal Arkeologi Papua Vol. 13 Edisi No. 1 / Juni 2021 : 31-48 


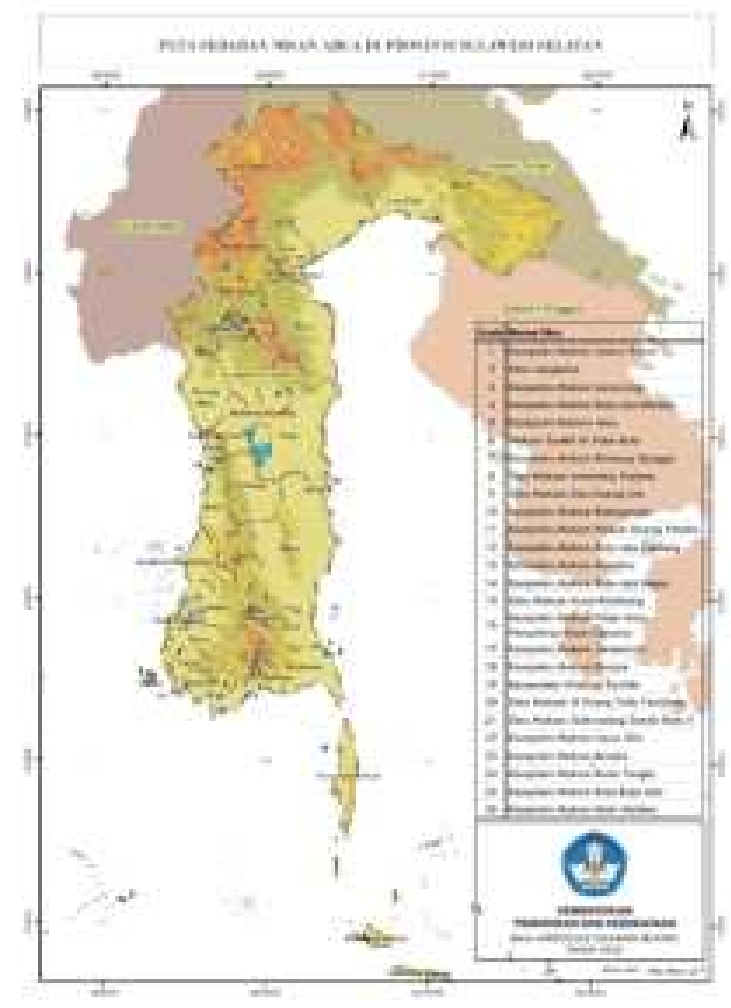

Gambar 10. Peta Persebaran Nisan Arca di Sulawesi Selatan

(Sumber: Balar Sulsel, 2020)

\section{PENUTUP}

Sulawesi Selatan terdiri dari 21 kabupaten, yaitu: Kepulauan Selayar, Bulukumba, Bantaeng, Jeneponto, Takalar, Gowa, Sinjai, Maros, Pangkajene dan Kepulauan, Barru, Bone, Soppeng, Wajo, Sidenreng Rappang, Pinrang, Enrekang, Luwu, Tana Toraja, Luwu Utara, Luwu Timur, Toraja Utara, serta tiga kota madya, yaitu: Makassar, Pare-pare dan Palopo. Sulawesi Selatan dihuni oleh tiga etnik besar, yaitu Etnik Makassar, Bugis dan Toraja, serta beberapa sub etnik lainnya. Nisan arca ditemukan di 13 kabupaten/kota di Sulawesi Selatan, pada wilayah etnik Bugis dan Makassar.
Nisan arca pada wilayah Etnik Bugis bisa ditemukan pada enam kabupaten di Sulawesi Selatan. Kabupaten pertama yaitu Baru pada Kompleks Makam Rajaraja Nepo dan Situs Makam Kuno Allakkang, kemudian di Bone nisan arca ditemukan di Kompleks Makam Nisan Arca di Pemukiman Kuno Cenrana, Kompleks Makam Jaramele'e dan Kompleks Makam Boccoe. Di kabupaten Pinrang nisan arca ditemukan di Kecamatan Watang Sawitto dan Situs Makam IX Puang Tallu Tombinna, di Sidenreng Rappang ada pada Situs Makam Sulewatang Sando Batu X, serta di Enrekang pada Kompleks Makam Laiya Alla, Kompleks Makam Baroko, Kompleks Makam Buntu Tangla dan Kompleks Makam Raja-raja Alla. Terakhir di Kabuputen Luwu, nisan arca ada pada Kompleks Makam Islam Matano. Nisan arca di wilayah Etnik Makassar ditemukan pada 12 situs yang tersebar di tujuh kabupaten/kota. Di Kabupaten Bantaeng nisan arca terdapat di Kompleks Makam La Tenri Rua, Situs Lamppora dan Kompleks Makam Lannying. Selanjutnya di Kabupaten Jeneponto ditemukan di Kompleks Makam Raja-raja Binamu, Joko, Syekh Ri Poko Bulo dan Karaeng Sengge. Kemudian, di Kabupaten Bulukumba pada Situs Makam Ammatoa Kajang dan Kompleks Makam Kuno Karaeng Dea Daeng Lita, di Kepulauan Selayar pada Kompleks Makam 
Batangmata, di Kabupaten Takalar ditemukan di Kompleks Makam Paduai daeng Palallo, di Makassar pada Kompleks Makam Raja-raja Sudiang dan yang terakhir pada di Kabupaten Maros pada Kompleks Makam Matakko. Namun, berdasarkan data pustaka terbaru, ada beberapa nisan arca yang telah hilang dari locusnya, di antaranya yaitu beberapa nisan arca di Kompleks Makam Raja-Raja Binamu, bagian kepala nisan pada Kompleks Makam Syekh ri Poko Bulo di Jeneponto, Raja-Raja Sudiang di Makassar, dan Paduai daeng Palallo di Takalar.
Seluruh data yang terkumpul merupakan hasil penelusuran data pustaka, sehingga diperlukan penelitian lebih lanjut untuk melakukan penelusuran secara mendalam terhadap keberadaan seluruh nisan arca di Sulawesi Selatan. Penelitian lapangan juga masih sangat diperlukan untuk melihat secara langsung perbandingan morfologi, termasuk krolonogi relatif pada masingmasing nisan arca di Sulawesi Selatan, baik itu di wilayah Etnik Bugis dan Makassar.

\section{DAFTAR PUSTAKA}

Azis, A. 1995. Kompleks Makam Kuno Islam Matano, Nuha, Luwu (Suatu Tinjauan Arkeologi). Universitas Hasanuddin.

Bahrir, S. 2009. Perbandingan Bentuk dan Ragam Hias Nisan Makam Islam pada Wilayah Pesisir dan Wilayah Pedalaman di Sulawesi Selatan. Universitas Hasanuddin Makassar.

Balai Arkeologi Makassar. 2010. Laporan Penelitian Arkeologi Kabupaten Wajo Sulawesi Selatan.

Balai Pelestarian Cagar Budaya Sulawesi Selatan. 2020. Berita Acara Serah Terima Arca Batu. Balai Pelestarian Peninggalan Purbakala Sulawesi Selatan. 2006. Laporan Studi Teknis Kompleks Makam Batangmata di Kabupaten Selajar Provinsi Sulawesi Selatan.

BPCB Makassar. 2013. Laporan: Survey Penyelamatan Gua Uhalie dan Gua Batti.

BPCB Sulsel. 2014. Laporan: Pendataan Cagar Budaya di Kabupaten Enrekang, Provinsi Sulawesi Selatan.

BPCB Sulsel. 2019. Pendataan Potensi Cagar Budaya Kawasan Benteng Kuno Cenrana Kabupaten Bone.

BPS Provinsi Sulawesi Selatan. 2019. Provinsi Sulawesi Selatan dalam Angka 2019. BPS Provinsi Sulawesi Selatan.

Hasnawati, Y. 1995. Kompleks Makam Kuno Raja-raja Sudiang di Sudiang (Suatu Tinjauan 
Arkeologis). Universitas Hasanuddin.

Husni, M., \& Hasanuddin. 2011. Potensi dan Sebaran Arkeologi Masa Islam di Sulawesi Selatan. Walennae, 12(1), 113-122. https://doi.org/10.24832/wln.v13i2.260

Iskandar, M. N. 2015. Laporan VIII Kegiatan Penyuluh Budaya Wilayah Kerja Kabupaten Sidrap dan Pinrang.

Jamaluddin. 1990. Bentuk Arca Nisan pada Situs Makam Kuna Bataliung di Jeneponto (Suatu Analisa Arkeologi). Universitas Hasanuddin.

Kementerian Pendidikan dan Kebudayaan Balai Pelestarian Peninggalan Purbakala. 2012. Peninggalan Sejarah Purbakala Kabupaten Takalar, Jeneponto, Bulukumba, Wajo dan Sidrap.

Mahmud, M. I. 2000a. Pemukiman Kuna Cenrana, Bone: Beberapa Aspek Data Sejarah-Sosial Bugis. Walennae, 3(2), 43-64. https://doi.org/10.24832/wln.v3i2.103

Mahmud, M. I. 2000b. Penelitian Arkeologi daerah Aliran Sungai Cenrana Kabupaten Bone, Sulawesi Selatan.

Mahmud, M. I. 2001. Determinasi Budaya Islami di Wilayah Pinggiran Kekuasaan Bugis. Walennae, 4(1), 73-90. https://doi.org/10.24832/wln.v4i1.122

Makmur. 2017a. Laporan Penelitian Arkeologi Jejak Peradaban Islam dan Kolonial di Kabupaten Bantaeng Sulawesi Selatan.

Makmur, M. 2017b. Ragam Hias dan Inskripsi Makam di Situs Dea Daeng Lita Kabupaten Bulukumba. Kalpataru, Majalah Arkeologi, 26(1), 15-26. https://doi.org/10.24832/kpt.v26i1.88

Mansyur, E. 2016. Fenomena Akulturuasi dan Sinkretisme dalam Perspektif Arkeologi: Ragam Hias di Kompleks Makam Bataliung Jeneponto, Sulawesi Selatan. Jurnal Walennae, 14(1), 45-62. https://doi.org/10.24832/wln.v14i1.40

Mene, B. 2011. Nisan Arca Situs Makam Kuno Manuba Kecamatan Mallusetasi Kabupaten Barru. Papua, 3(1), 39-50. https://jurnalarkeologipapua.kemdikbud.go.id/index.php/jpap/article/view/93

Muhaeminah. 1996. Tipe Nisan Makam Kuna di Kecamatan Pammana Kabupaten Wajo.

Muhaeminah. 2008. Kubur Islam Kuno di Pesisir Sulawesi Selatan dan Sulawesi Barat. Walennae, 10(2), 62-70. https://doi.org/10.24832/wln.v10i2.192

Natsir, Z., Peseletehaha, G. A. S., Usman, N., \& Nuarasia. 2011. Laporan Pengenalan Dasar Studi Lapangan Arkeologi (Landasstular) XX Bulukumba.

Nur, M., \& Hasanuddin. 2017. Unsur budaya Prasejarah dan Tipo-kronologi Nisan di Kompleks Makam Mattakko, Maros, Sulawesi Selatan. Arkeologi Papua, 9(1), 59-70. 
https://jurnalarkeologipapua.kemdikbud.go.id/index.php/jpap/article/view/207

Nur, M., Hasanuddin, Duli, A., Rosmawati, \& Mansyur, S. 2019. Transformasi Arca Menhir

Menjadi Nisan Arca di Wilayah Makassar, Sulawesi Selatan, Indonesia. Seminar Antarbangsa Ke-8 Arkeologi, Sejarah, Bahasa Dan Budaya Di Alam Melayu.

Rahman, D. M., Muhaeminah, Sonda, H., \& Sila, S. 1994. Seni Khat dan Ajaran Agama Islam

di Dalam Inskripsi Kaligrafi Arab dan Lontara pada Makam Islam Bahagian Selatan Kotamadya Makassar.

Rosmawati. 2013. Perkembangan Tamadun Islam di Sulawesi Selatan, Indonesia: dari Perspektif Arkeologi dan Sejarah. Universiti Sains Malaysia.

Sande, J. S., Adri;, Manuputry, D., Syahril, N. A., \& Eppang, M. 1997. Tata Bahasa Toraja. Departemen Pendidikan dan Kebudayaan.

Saprillah;, Idrus, M., Narsih, W., Rislah;, \& Munandar. 2012. Sejarah Sosial Masyarakat Rongkong. BPNB Makassar.

Sarjiayanto. 2000. Potensi Data Arkeologi Situs Cenrana: Kajian Awal Bagi Studi Pemukiman. Wale, 3(1), 67-82.

Sitonda, M. N. 2013. Pancaitana Bungawalie: Perjuangan Rakyat Maiwa, Duri Melawan Kolonialisme Belanda. YPMN.

Suaka Peninggalan Sejarah dan Purbakala Sulawesi Selatan. 1983. Laporan Pengumpulan Data Peninggalan Sejarah dan Purbakala Kabupaten Jeneponto.

Suaka Peninggalan Sejarah dan Purbakala Sulawesi Selatan. 1984. Laporan Pengumpulan Data Peninggalan Sejarah dan Purbakala.

Syukur, S. 2015. Sistem Pemerintahan Kedatuan Luwu dalam Kurun Periode I Lagaligo. 3(1), $25-34$.

Tim Peneliti Balai Arkeologi Sulawesi Selatan. 2011. Laporan Penelitian Arkeologi Pesisir Selatan Sulawesi Selatan.

Utomo, W. D. 2000. Pengaruh Tradisi dan Simbol Megalitik pada Makam Kuna Islam di Sulawesi Selatan. Walennae, 3(2), 13-28. https://doi.org/10.24832/wln.v3i2.101

Wardaninggar, B. K. 2016. Sebaran Potensi Budaya Prasejarah di Enrekang, Sulawesi Selatan. Kapata Arkeologi, 12(2), 113-124. https://doi.org/10.24832/kapata.v12i2.326

Wulandari, F. 2011. Pemukiman di Sisi Selatan Tepi Aliran Sungai Cenrana. Universitas Hasanuddin.

Wulandari, F. 2017. Aspek Ruang Pemukiman Di Sisi Selatan Tepi Aliran Sungai Cenrana, Kabupaten Bone. Jurnal Walennae, 15(2), 101. https://doi.org/10.24832/wln.v15i2.274 
Zerasmita. 2007. Tipe-Tipe Nisan pada Kompleks Makam Kuna Karaeng Dea Daeng Lita di Kecamatan Kajang Kabupaten Bulukumba. Universitas Hasanuddin. 